\title{
Küresel Sosyal Sorumluluk Ölçeği: Geçerlik ve Güvenirlik Çalışması*
}

\author{
Enis Harun BAŞER ${ }^{* *} \quad$ Emin KILINÇ***
}

Öz

Günümüzde karşı karşıya kalınan çevre kirliliği, ozon tabakasının incelmesi, küresel ısınma, nükleer facialar, savaş ve çatışmalar gibi küresel sorunların çoğu insan kaynaklı problemlerdir. Sadece insanları değil tüm doğayı ve canlıları etkileyen bu tür sorunların hem kaynağı hem de çözümü insandır. Bireyleri küresel sorunların çözümüne yöneltecek ve bu doğrultuda harekete geçirecek unsurlardan en önemlisi, bireylerin kendilerini bu durumdan sorumlu hissetmeleridir. Bu bağlamda bu araştırmada sorumluluk küresel bir bağlamda ele alınacaktır. Bu çalışmanın amacı, sosyal bilgiler öğretmen adaylarının küresel sosyal sorumluluk düzeylerini ölçmeye yönelik geliştirilen ölçeğin geçerlik ve güvenirliğini incelemektir. Küresel sosyal sorumluluk ölçeğinin geliştirilmesi amac1yla öncelikle ilgili literatür (Berkowitz ve Lutterman, 1968; Ercan, 2009; Nakamura ve WatanabeMuraoka, 2006; Öcal, Demirkaya ve Altınok, 2013; Önal, 2005; Starret, 1996) taranmış ardından sosyal sorumluluğu küresel boyuta taşıyacak evrensel değerler (Braithwaite ve Law 1985; Akt: Starret, 1996; Eisenberg 1986; Akt: Starret, 1996; Schwartz, 1992) göz önüne alınarak ölçek maddeleri oluşturulmuştur. Yapılan açımlayıcı faktör analizi sonucu ölçeğin dört boyutlu bir yapı sergilediği bulunmuştur. Ölçeğin güvenirliğine ilişkin bulgular için Cronbach Alfa katsayıları hesaplanmış ve ölçeğin tamamında .89, ilk alt boyutunda (Eyleme Dönük Sorumluluk) .88, ikinci alt boyutunda (Ekolojik Sorumluluk) .74, üçüncü alt boyutunda (Özgeci Sorumluluk) .77 ve dördüncü alt boyutunda (Ulusal Sorumluluk) ise .73 bulunmuştur.

Anahtar Kelimeler: Küresel sosyal sorumluluk, öğretmen adayı, sorumluluk.

\section{Global Social Responsibility Scale: Validity and Reliability}

\section{Study}

\begin{abstract}
Today, global issues such as environmental pollution, destruction of ozone layer, global warming, nuclear disasters, wars and conflicts are all man-made problems. Both the reasons and the solutions of these problems which have been affecting mankind, nature and other creatures are in the hands of people. The most important factor that will canalize and impel people about the solution of global problems is to feel responsible as individuals. So, in this study responsibility will be discussed globally. The purpose of this study is to examine validity and reliability of the scale which has been developed to evaluate social responsibility levels of social studies prospective teachers. Firstly, related books and articles (Berkowitz and Lutterman, 1968; Ercan, 2009; Nakamura and Watanabe-
\end{abstract}

\footnotetext{
${ }^{*}$ Bu çalışma birinci yazarın yüksek lisans tezinden üretilmiştir.

** Dumlupınar Üniversitesi, İlköğretim Bölümü, enisharunbaser@gmail.com

*** Dumlupınar Üniversitesi, İlköğretim Bölümü, emin.kilinc@dpu.edu.tr
} 
Muraoka, 2006; Öcal, Demirkaya and Altınok, 2013; Önal, 2005; Starret, 1996) are studied in order to develop the social responsibility scale and then the scale items are created according to universal values (Braithwaite and Law 1985; Akt: Starret, 1996; Eisenberg 1986; Akt: Starret, 1996; Schwartz, 1992) which provide to examine social responsibility globally. In accordance with the results of exploratory factor analysis, it is concluded that the scale has a four-dimensional form. Cronbach Alpha coefficients are calculated for the findings related to the reliability of scale and it is .89 for the whole scale, .88 for the first sub-dimension (Action Oriented Responsibility), .74 for the second subdimension (Ecological Responsibility), .77 for the third sub-dimension (Altruist Responsibility), .73 for the fourth sub-dimension (National Responsibility).

Keywords: Global Social responsibility, pre-service social studies Teachers, responsibility.

\section{GİRIŞ}

Son yıllarda sanayi, eğitim, teknoloji, insan hakları gibi pek çok alanda meydana gelen gelişmeler toplumların yapısında ve insanların sosyal yaşantılarında önemli değişikliklere yol açmıştır. Sorumluluk kavramı bu gelişmelerle birlikte üzerinde daha çok durulan bir kavram haline gelmiştir. Özellikle büyük savaşların, yıkımların ve ekonomik buhranların ardından sorumluluk kavramının sosyal boyutuna daha çok vurgu yapilır olmuştur. Ulaşım, bilgi teknolojileri ve haberleşme gibi insanları birbirine bağlayan köprülerin hızla gelişimi insanların, toplumların ve devletlerin etkileşimini artırarak küreselleşme olgusunun diğer gelişmelerle birlikte hızla büyümesine, yayılmasına olanak sağlamıştır. Küreselleşme olgusuyla birlikte sosyal sorumluluk kavramı evrensel bir boyut kazanmış ve sosyal sorumluluk kavramının sınırları, yaşanılan toplumu aşarak tüm dünyayı kapsayacak şekilde genişlemiştir.

Sorumluluk, insanların davranışlarının veya olumsuz neticeler doğurabilecek olaylara müdahale etmedikleri durumların sonuçlarını kabullenebilmesi olarak tanımlanabilir (Dökmen, 2000). Sorumluluk olgusu insanoğlu var olduğu günden bugüne süregelmiştir. Sorumluluk bilinci aile içerisinde temellenerek çevre ve eğitim etkisiyle gelişmektedir. Değer temelli sorumluluk bilinci kontrol edilebilir bir faktör olarak eğitimle bireylere sistematik bir şekilde kazandırılmaya çalışılmaktadır. Bireylerin sorumluluk kavramını içselleştirmeleri, toplumun istediği yönde sorumluluk bilinci kazanması ve topluma yarar sağlayacak davranışlarda bulunması için bu kavramın sistemli ve planlı bir şekilde eğitimle kazandırılması önemlidir. Bu amaçla ülkemizde ilkokullardan başlanarak (hayat bilgisi, sosyal bilgiler) yükseköğretim düzeyine kadar (topluma hizmet uygulamaları) sorumluluk bilinci kazandırılmasını amaçlayan dersler konulmuştur. Eğitimle verilmek istenen sorumluluk değeri çalışmamızın hareket noktasını oluşturmuştur.

\section{1 Sorumluluk}

İnsan toplum içerisinde diğer bireylerle etkileşim halinde hayatını sürdürmekte ve bu durum da bireye toplumla yaşamanın gereği birtakım görev ve sorumluluklar yüklemektedir. Bireyin gelişim düzeyine, yaşına ve cinsiyetine uygun görev ve yükümlülükleri ifa etmesi sorumluluk kavramını işaret etmektedir (Yavuzer, 1995). Şirin (2005) sorumluluğu, bireyin davranışının neticesinde meydana gelen bir durum olarak tanımlamış ve sorumluluğu doğası gereği sınırlandırılmış olan temel hukuki haklardan doğan görev ve yükümlülüklerle ilişkilendirmiştir. Sorumluluk kavramı Türk Dil Kurumu'na (2014) göre “kişinin kendi davranışlarını veya kendi yetki alanına giren herhangi bir olayın sonuçlarını üstlenmesi, sorum, mesuliyet" olarak tanımlanmaktadır. Başaran (1971) sorumluluğa bir duygu olarak yaklaşmış ve sorumluluğu üstlenilen görevleri veya yapılması için verilen işleri ne olursa olsun sonuna kadar yapma ve gerektiğinde hesap verebilme ile ilgili bir duygu olarak değerlendirmiştir (Akt: Sezer, 2008). Daha geniş bir bakış açısıyla sorumluluk bireylerin toplumsal, ulusal ve küresel neticeler doğurabilen davranışları sonucunda meydana gelen durumları kabullenmesi ve olumsuz etkileri varsa bunların önüne geçmeye çalışması olarak değerlendirilebilir (Özen, 
2009). Ancak unutmamak gerekir ki, hem bireysel hem de toplumsal boyutu olan sorumluluk anlayışı, içinde bulunduğu sosyal yapının değer yargılarına bağlı olarak farklılık gösterebilmektedir (Sert, 2012). Bu araştırmada sorumluluk kavramına, yukarıdaki tanımların ortak noktalarını kapsayacak şekilde yaklaşılmıştır. Buna göre sorumluluk; bireyin toplum tarafından beklenen görev ve yükümlülüklerini yerine getirmesi, sadece kendi davranışlarını değil yetki alanına giren diğer durumları da üstlenmesi ve daha iyi bir dünya için çaba sarf etmesidir.

\section{2 Sosyal Sorumluluk}

Bireyler aile içinde aldıkları terbiye, inandıkları dinin kuralları, gelenekler, örf ve adetler, görgü kuralları gibi bir takım nedenlerden dolayı sosyal bir şekilde hareket ederler (Torlak, 2007). İyilik yapma ve iyi bir insan olma duyguları sosyal sorumluluk kavramının oluşumunda önemli bir yere sahiptir. Tek tanrılı dinler veya diğer geniş kapsamlı inanç sistemleri insanları faydalı birer birey olma doğrultusunda yönlendirmekte ve bu idealde telkinlerde bulunmaktadır. Bu doğrultuda insanlar servetlerinin, varlıklarının veya zamanlarının bir kısmını diğer insanların yararına kullanmakta ve kendini gerçekleştirme amacıyla hareket etmektedirler. Böylece hem içerisinde yaşadıkları cemiyet gözünde hem de inandıkları inanç sisteminde iyi bir konuma gelmeye uğraşmaktadırlar (Güngör, 2010).

Sorumluluk insanların hem kendisi için hem de toplum için oluşturduğu duygu, düşünce ve davranış örüntülerinin birlikteliğiyle oluşur (Duman, 2014). Dolayısıyla sorumluluğun toplumsal boyutu da mevcuttur. Toplum içerisinde yaşayan her bir bireyin yerine getirebileceği bir takım sosyal sorumlulukları mevcuttur. İçinde yaşanılan toplumun sorunlarına karşı bireylerin duyarlı olması ve toplumun gelişimi yönünde çalışmalara katılması ve bu çalışmalar1 desteklemesi gerekmektedir (Yılmaz, 2006). Sosyal sorumluluk Berman'a (1990) göre diğer insanların refahı ve gezegenin yararı için yapılan kişisel yatırımlardır. Öztürk (2003) ise sos- yal sorumluluğu, toplumun refah durumuna katkı yapılması ve mevcut refahın da bozulmaması için üstlenilmesi gereken sorumluluklar bütünü olarak tanımlamaktadır. Tam ve Yeung (1999) batı kültüründe sosyal sorumluluğu ahlaki yükümlülük ve toplumsal bağlılık kavramları etrafında kolektivist bir yaklaşımla herkesin yararlandığı sosyal refah durumunu destekleyen bir olgu olarak açıklamışlardır. Torlak (2003) sosyal sorumluluğun, kişisel sorumlulukların bireyin çevresini de kapsamaya başladığı andan itibaren başladığını ifade etmiştir. Schwartz (1992) ise bir değer olarak sosyal sorumluluğu kendini geliştirmenin ötesinde kendini aşma durumu olarak tanımlamıştır.

\section{3 Küresel Sosyal Sorumluluk}

Küreselleşmenin etkisini artırması ile birlikte daha çok ulusal çerçevede düşünülen sosyal sorumluluk artık küresel bağlamda düşünülmeye başlanmıştır (Starret,1996). Küresel sosyal sorumluluk bireylerin topluma karşı olan sorumluluklarını küresel bağlamda birbirine bağlayan bir kavramdır (Nakamura ve Watanabe-Muraoka,2006). Sosyal sorumluluğun küreselleşmesi ve daha geniş anlamda düşünülmesiyle birlikte sosyal sorumluluğun kapsamı genişlemiş, toplumsal sorunların çözümüne yönelik düşünülen sorumluluklar küresel sorunların çözümüne doğru büyümüştür.

Küresel sosyal sorumluluk bütün canlılara, doğaya ve tüm bunların bir bütün olarak meydana getirdiği dünyaya karşı sorumlu olma durumuyla ilgilidir. Doğal çevrenin kirlenmesi, küresel ısınma, ozon tabakasının incelmesi, elektro manyetik alanların yaydığı tehlike, silahlı çatışmalar, olumsuz toplumsal alışkanlıklar gibi yeryüzünü ve insanlığı tehdit edebilen büyük sorunların önüne geçilmesi küresel sosyal sorumluluğu kişiliğinin bir parçası haline getirmiş ve bunu etkili bir biçimde eyleme dönüştürebilen insanlarla mümkün olabilir. Küresel sorunların çözümü için her bireyin yerine getirebileceği mutlaka birtakım sorumlulukları vardır (Özen, 2009). 
Küreselleşmeyle birlikte eğitimin muhteviyatında, işleniş şeklinde, yapısında birtakım değişiklikler meydana gelmektedir. Öğrenciler küresel meselelerle ilgili bilgilerle artık daha fazla karşılaşmaktadırlar. Bu durum 21. yüzyıl öğrencilerinin eğitiminde küresel meselelerle ilgili farkındalık ve bilgi düzeyleri yüksek öğretmenleri önemli bir hale getirmektedir. Öğretim paradigmasının değişen dünya koşullarını ve buna bağlı oluşan yeni talep ve ihtiyaçları karşılamak için değişmesi gerekmektedir. Küreselleşmeyi benimseyebilmiş öğretmenlerin öğrencilerini gerekli yetenek, beceri ve bilgilerle donatması gerekmektedir (Richardson, 2012). Bilgi, yetenek ve beceri bunları toplum ve insan yararına kullanabilme sorumluluğuna erişmiş insanların elinde bir anlam kazanmakta ve büyük bir güce dönüşebilmektedir. Özellikle gönüllülük temelli toplum yararına hissedilen sorumluluk anlayışıyla hareket etmek toplumların refahını, insanların yaşam kalitesini ve standardını yükselterek arzu edilebilir bir toplum yapısı ve dünya oluşumuna olanak sağlayacaktır. Bu bağlamda bu araştırmanın amacı; toplumların geleceğinin temellerini oluşturan nesilleri yetiştirecek olan öğretmen adaylarının küresel sosyal sorumluluklarını ölçmeye yönelik bir ölçek geliştirmektir.

Sosyal sorumluluk kavramı ile yapılan çalışmalarda genellikle bireysel, toplumsal ve kurumsal boyutta yoğunlaşılmış (Bozkurt, 2009; Eraslan, 2011; Hull, 2002; İşseveroğlu, 2001; Pelit, Keleş ve Çakır, 2009; Wildowicz-Giegiel, 2014), küresel boyutta ise genellikle işletme bazında kurumsal sosyal sorumluluk kavramına ağırlık verilmiştir (Çelik, 2007; Güngör, 2010; Vural ve Coşkun, 2011). Yurtiçinde eğitimle sosyal sorumluluk ilişkisinin kurulduğu araştırmalarda ise küresel etkilere pek fazla vurgu yapılmamıştır (Eren, 2011; Şirin, 2005; Y1lmaz, 2011). Bu araştırmada sosyal sorumluluk, küresel bazda değerlendirilerek bu alanda yapılacak çalışmalarda kullanılması beklenen küresel sosyal sorumluluk ölçeği geliştirilmiştir.

\section{YÖNTEM}

Araştırma kapsamında oluşturulan küresel sosyal sorumluluk ölçeğinin geliştirilmesine yönelik çalışmalara aşağıda yer verilmiştir.

\section{1 Çalışma Gurubu}

Hazırlanan 48 maddelik taslak ölçek 2014-2015 eğitim ve öğretim yılı güz döneminde Dumlupınar Üniversitesi Eğitim Fakültesi İlköğretim Bölümü Sosyal Bilgiler Öğretmenliği Anabilim Dalında öğrenim gören tüm öğretmen adaylarına gönüllülük esasına uygun olarak uygulanmıştır. Eksik ve yanlış doldurulan formlar çıkarıldığında toplamda 327 form elde edilmiştir. Çalışmaya katılan öğretmen adaylarının 170'i (\%52) kadın, 157'si (\%48) erkek, yaş ortalamaları ise $21^{\prime}$ dir.

\section{2 Veri Toplama Aracının Geliştirilmesi}

Literatür tarandıktan sonra sosyal sorumluluğu oluşturan sekiz boyutlu (Ekonomik, sağlık, eğitim, politik, ekolojik, özgeci, ulusal ve eyleme dönük sorumluluk) bir ölçek geliştirmek amaçlanmıştır. Ancak boyutlardan ikisi (Ekonomi ve sağlık) ölçeği küresel bir boyuta taşıyacak olan evrensel değerleri yansıtması bağlamında incelendikten ve 2014-2015 öğretim yılında Dumlupınar Üniversitesi Pedagojik Formasyon öğrencilerinden elde edilen veriler çözümlendikten sonra ölçekten çıkarılmıştır. Bir diğer boyut (Politika) ise kapsam geçerliliği aşamasında ölçekten çıkarılmıştır. Diğer bir boyut (Eğitim) ise yapılan açımlayıcı faktör analizi sonrası ölçekten çıkarılmıştır.

\section{3 Madde Havuzu Oluşturma Aşaması}

Küresel sosyal sorumluluk ölçeğinin geliştirilmesi amacıyla öncelikle literatür taranarak, Sosyal Sorumluluk Veri Toplama Aracı (Ercan, 2009), Sorumluluk Tutum Ölçeği (Önal, 2005), Küresel Sosyal Sorumluluk Ölçeği Envanteri (Starret, 1996), Sosyal Duyarlılık Ölçeği (Öcal, Demirkaya ve Altınok, 2013), Sosyal Sorumluluk Ölçeği (Berkowitz ve Lutterman, 1968), Küresel Sosyal Sorumluluk Ölçeği (Nakamura ve Watanabe-Muraoka, 2006) envanter ve ölçeklerinden de yararlanarak 110 madde oluşturulmuştur. Sonraki aşamada; 2014-2015 öğretim yılında Dumlupınar Üniversitesi Pedagojik 
Formasyon eğitimi alan 89 öğrenciye "Küresel sosyal sorumluluklarınız nelerdir?" sorusu yöneltilmiştir. İçerik analiziyle çözümlenen cevaplar literatür yardımıyla oluşturulan madde havuzuyla karşılaştırılmış, örtüşen maddeler ile evrensel değerleri yansitan maddeler seçilerek 73 maddelik madde havuzu oluşturulmuştur. Ölçek maddelerine ve ölçeğe küresel bağlamı katan ve yukarıda bahsi geçen evrensel değerler ise Schwartz'ın (1992) araştırmasında ifade ettiği ve konumuzla ilgili evrensel değerler (eşitlik, sosyal adalet, dünya barışı, çevreyi koruma, açık fikirlilik), Braithwaite ve Law'un (1985; Akt: Starret, 1996) araştırmalarında belirtilen değerler (uluslararası işbirliği, doğa ile bütünleşmek) ve Eisenberg'ün (1986; Akt: Starret, 1996) olumlu sosyal muhakemede en üst seviyelerde tanımladığ (tüm insanlar için refah) değerlerdir.

\section{4 Uzman Görüşüne Başvurma Aşaması (Kapsam Geçerliliği)}

Geçerlik, testin bireyin ölçülmek istenen özelliğini ne derece doğru ölçtüğüyle ilgili bir kavramdır. Testi oluşturan maddelerin ölçülmek istenilen davranışı ölçmede nicelik ve nitelik olarak yeterli olup olmadığının göstergesi olan kapsam geçerliliğini test etmede sıkça kullanılan yöntemlerden biri de uzman görüşlerine başvurmaktır (Büyüköztürk, 2011, 168). Hazırlanan 73 maddeli taslak ölçek Ölçme Değerlendirme, Türkçe ve Sosyal Bilgiler Öğretimi öğretim üyesi ve elemanlarından oluşan yedi uzman yardımıyla incelenmiştir. Anlamın net olmadığı, aynı kapsamı ölçtüğü ve dil bilgisi konusunda sıkıntıları olduğu düşünülen maddelerin çıkarılmasıyla taslak ölçekteki madde sayısı 48'e inmiştir. 48 maddelik ölçeğin 16's1 olumsuz, 32'si ise olumlu yarg1 içermektedir. 48 maddelik ölçek 5'li likert tipinde geliştirilmiş, olumlu maddeler kesinlikle katılmıyorum (1), katılmıyorum (2), kararsızım (3), katılıyorum (4) ve kesinlikle katıliyorum (5) şeklinde puanlanmış, olumsuz maddeler ise puanlama aşamasında ters çevrilmiştir. Buna göre ölçek- ten elde edilebilecek en yüksek puan 240, en düşük puan 48 olacaktır.

\section{BULGULAR}

\section{1. Yapı Geçerliği}

Yapı geçerliliğini test etmek ve aynı niteliği ölçen değişkenleri bir araya getirerek, ölçmeyi az sayıda faktör ile açıklamak amacıyla faktör analizi yapılması gerekmektedir (Büyüköztürk, 2011, 123). Bu amaçla, değişkenler arasındaki ilişkilerden hareket ederek faktör bulmaya yönelik açımlayıcı faktör analizi yapılmıştır.

Açımlayıcı faktör analizinin (AFA) yapılabilmesi için Kaiser-Meyer-Olkin (KMO) değerinin en az .60 olması ve Bartlett Sphericity testinin anlamlı çıkması gerekmektedir (Büyüköztürk, 2011, 126). Bundan dolayı açımlayıcı faktör analizi yapılmadan önce verilerin faktör analizine uygunluğu KMO ve Bartlett Sphericity testiyle belirlenmiştir. KMO değeri .86 olarak bulunmuş ve dolayısıyla veri yapısının faktör analizi yapabilmek için yeterli olduğu değerlendirmesi yapılmıştır. Bartlett Sphericity testi ise ( $x 2=5291.165, \mathrm{p}=.000)$ anlamlı bulunmuştur. Bu sonuç verilerin çok değişkenli normal dağılımdan geldiğini ve dolayısıyla faktör analizinin bir diğer sayıltısının karşılandığı anlamına gelmektedir (Çokluk, Şekercioğlu ve Büyüköztürk, 2012). Bu sonuçlardan elde edilen verilerin faktör analizi yapmaya uygun olduğu neticesine varılmıştır.

Veri seti üzerinden yapılan faktör analizinde faktör özdeğeri 1'den büyük olan faktörler anlamlı olarak belirlenmiş, temel bileşenler analizi öncelikli olmak üzere varimax eksen döndürmesi gerçekleştirilmiştir. Yapılan analiz sonucu başlangıçta öz değeri 1'in üzerinde olan 14 bileşen bulunmuştur. Şekil 1'de görüldüğü üzere Yamaç Eğim Grafiği (Scree Plot) incelenerek ölçeğin 4 faktörlü olması gerektiği sonucuna varılmış ve faktör sayısı 4 ile sınırlandırılarak tekrar işlem yapılmıştır. 


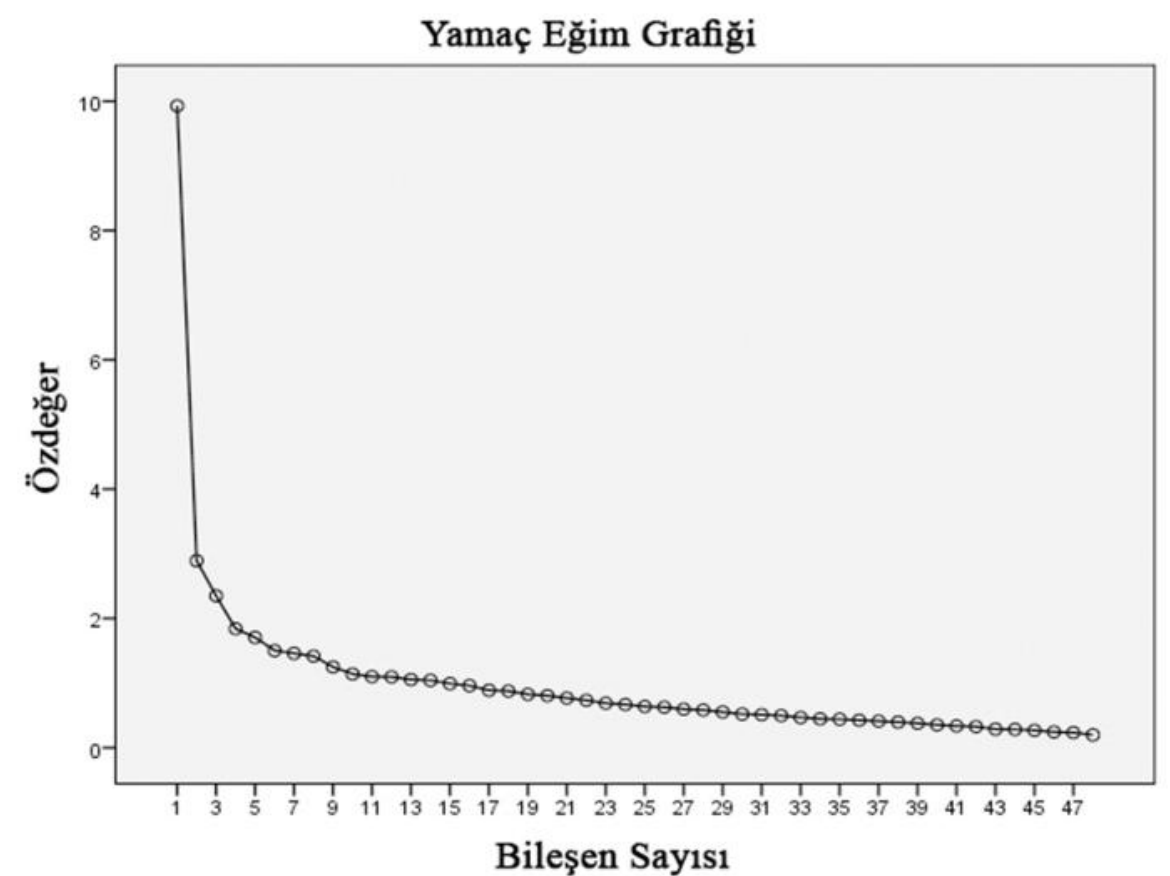

Şekil 1. Yamaç Eğim Grafiği

Yapıdaki faktörlere karar verildikten sonra maddelerin faktörlerdeki yükleri ve binişik olma durumları incelenmiştir. Faktör yük değerlerinin .45 yada daha yüksek olması seçim için iyi bir ölçüt olmakta ancak uygulamada az sayıda madde için bu sınır .30'a kadar indirilebilmektedir. Ayrıca faktör yüklerinin binişik sayılmaması için aralarındaki farkın en az 0,1 olması önerilmektedir (Büyüköztürk, 2011, 124). Açımlayıcı faktör analizinde maddelerin ölçekte kalıp kalmamasına karar vermede faktör yük değerinin alt sınırı .45 olarak benimsenmiştir. Ancak gerçekleştirilen analizler sonucu .40 üzerinde ancak .45 ten düşük değer gösteren 41. maddenin ölçekte kalmasına karar verilmiştir. Yapılan analizler sonucu binişik olduğu tespit edilen 1, 9, 13, 24, 26 ve 40 numaralı maddeler ve faktör yükünü karşılamayan
$4,6,7,8,15,19,21,22,23,32$ ve 47 numaralı maddeler ölçekten çıkarılmıştır. Ayrıca madde 34 aynı faktör altındaki diğer maddelerle anlam bütünlüğü sağlamadığı düşünülerek ölçekten çıkarılmıştır. Bu maddelerin analiz dışı bırakılması sonucu elde edilen faktör deseni ve maddelerin faktör yük değerleri Tablo 1'de verilmiştir. Yapılan analizler sonucunda ölçeğin son hali 4 faktörlü ve 9'u olumsuz 21'i olumlu yargı içeren toplam 30 maddeli bir yapı sergilemektedir.

Tablo 1'de görüldüğü üzere alt ölçekler düzeyinde faktör yük değerleri birinci faktör için .71 ile .49 arasında, ikinci faktör için .74 ile .57 arasında, üçüncü faktör için .70 ile .47 arasında ve dördüncü faktör için .74 ile .42 arasında değişmektedir. 
Tablo 1. Küresel Sosyal Sorumluluk Ölçeği Faktör Deseni

\begin{tabular}{|c|c|c|c|c|}
\hline Madde No. & 1. Faktör & 2. Faktör & 3. Faktör & 4. Faktör \\
\hline 43 & 708 & & & \\
\hline 33 & .706 & & & \\
\hline 38 & .705 & & & \\
\hline 36 & .689 & & & \\
\hline 44 & .676 & & & \\
\hline 14 & .646 & & & \\
\hline 27 & .586 & & & \\
\hline 30 & .578 & & & \\
\hline 28 & .566 & & & \\
\hline 31 & .540 & & & \\
\hline 48 & .513 & & & \\
\hline 5 & .490 & & & \\
\hline 42 & & .737 & & \\
\hline 39 & & .703 & & \\
\hline 37 & & .617 & & \\
\hline 45 & & .599 & & \\
\hline 46 & & .572 & & \\
\hline 10 & & & .699 & \\
\hline 11 & & & .643 & \\
\hline 3 & & & .602 & \\
\hline 2 & & & .599 & \\
\hline 12 & & & .580 & \\
\hline 18 & & & .516 & \\
\hline 16 & & & .471 & \\
\hline 29 & & & & .743 \\
\hline 17 & & & & .740 \\
\hline 35 & & & & .686 \\
\hline 25 & & & & .534 \\
\hline 20 & & & & .495 \\
\hline 41 & & & & .425 \\
\hline $\begin{array}{l}\text { Analiz dışı bırakı } \\
\text { faktör için tekraı } \\
\text { 2'de görüldüğü i } \\
\text { yansa yaptıkları } \\
\text { \%18, ikinci faktör } \\
\text { \%9.78 ve dördün } \\
\text { görülmüştür. Beliı }\end{array}$ & $\begin{array}{l}\text { eler ardından dört } \\
\text { aliz sonucu, Tablo } \\
\text { orlerin toplam var- } \\
\text { birinci faktör için } \\
\text { üçüncü faktör için } \\
\text { için \%9.53 olduğu } \\
\text { t faktörün varyansa }\end{array}$ & \multicolumn{3}{|c|}{$\begin{array}{l}\text { yaptıkları toplam katkı ise } \% 47.23 \text { 'dür. Çok } \\
\text { faktörlü desenlerde açıklanan varyansın } \% 40 \\
\text { ile \%60 arasında olması yeterli olarak kabul } \\
\text { edilir (Büyüköztürk, 2007). Bu bağlamda tanım- } \\
\text { lanan faktörlerin toplam varyansa yaptığı kat- } \\
\text { kının yeterli olduğu görülmektedir. }\end{array}$} \\
\hline \multicolumn{5}{|c|}{ Tablo 2. Küresel Sosyal Sorumluluk Ölçeği Açıklanan Varyans Değerleri } \\
\hline \multicolumn{2}{|c|}{ Faktörler } & \multicolumn{3}{|c|}{ Açılanan Varyans Değerleri (\%) } \\
\hline \multicolumn{2}{|c|}{ 1. Faktör (12 Madde) } & \multicolumn{3}{|c|}{18.005} \\
\hline \multicolumn{2}{|c|}{ 2. Faktör (5 Madde) } & \multicolumn{3}{|c|}{9.909} \\
\hline \multicolumn{2}{|c|}{ 3. Faktör (7 Madde) } & \multicolumn{3}{|c|}{9.784} \\
\hline \multicolumn{2}{|c|}{ 4. Faktör (6 Madde) } & \multicolumn{3}{|c|}{9.530} \\
\hline \multicolumn{2}{|c|}{ Açıklanan Toplam Varyans Değeri (30 Madde) } & \multicolumn{3}{|c|}{47.229} \\
\hline
\end{tabular}

Faktörler barındırdıkları maddelerin içerdiği ifadelere göre isimlendirilmiştir. Buna göre birinci faktör "Eyleme Dönük Sorumluluk", ikinci faktör "Ekolojik Sorumluluk", üçüncü 
faktör "Özgeci Sorumluluk", dördüncü faktör ise "Ulusal Sorumluluk" olarak isimlendirilmiştir.

Gerçekleştirilen faktör analizi sonuçlarını yapısal geçerlilik kanıtı olarak sunma biçimlerinden biri de boyutlar arası ilişkidir (Şencan, 2005). Bu bağlamda yapı geçerliliğine ek kanıt olarak ölçeğin boyutları ve genel toplam puanı arasındaki ilişkiler incelenmiş olup Pearson Korelasyon katsayıları hesaplanmıştır.

Tablo 3. Pearson Korelasyon Katsayıları

\begin{tabular}{|c|c|c|c|c|c|c|}
\hline & & Faktör 1 & Faktör 2 & Faktör 3 & Faktör 4 & Toplam \\
\hline \multirow[t]{2}{*}{ Faktör 1} & $\begin{array}{c}\text { Pearson Korelasyon } \\
\text { Katsayıs1 }\end{array}$ & 1 &, $501^{* *}$ &, $499 * *$ &, $362^{* *}$ & $858^{* *}$ \\
\hline & Anlamlılık & & .000 & .000 & .000 & .000 \\
\hline \multirow[t]{2}{*}{ Faktör 2} & $\begin{array}{c}\text { Pearson Korelasyon } \\
\text { Katsayısı }\end{array}$ &, $501^{* *}$ & 1 &, $408^{* *}$ &, $294^{* *}$ & $668^{* *}$ \\
\hline & Anlamlılık & .000 & & .000 & .000 & .000 \\
\hline \multirow[t]{2}{*}{ Faktör 3} & $\begin{array}{c}\text { Pearson Korelasyon } \\
\text { Katsayıs1 }\end{array}$ & $499^{* *}$ & $408^{* *}$ & 1 & $457^{* *}$ &, $756^{* *}$ \\
\hline & Anlamlılık & .000 & .000 & & .000 & .000 \\
\hline \multirow{2}{*}{ Faktör 4} & $\begin{array}{c}\text { Pearson Korelasyon } \\
\text { Katsayısı }\end{array}$ &, $362^{* *}$ &, $294^{* *}$ & $457^{* *}$ & 1 & ,692** \\
\hline & Anlamlılık & .000 & .000 & .000 & & .000 \\
\hline \multirow[t]{2}{*}{ Toplam } & $\begin{array}{c}\text { Pearson Korelasyon } \\
\text { Katsayıs1 }\end{array}$ & $858^{* *}$ & $668^{* *}$ &, $756^{* *}$ & ,692** & 1 \\
\hline & Anlamlilık & .000 & .000 & .000 & .000 & \\
\hline
\end{tabular}

Küresel sosyal sorumluluk ölçeğinden alınan toplam puanlar ile bu ölçeğin alt faktörleri arasındaki korelâsyon katsayısı sonuçları incelendiğinde (Tablo 3) orta ve yüksek düzeyde pozitif bir ilişki çıkmıştır ( $r=.858, .668, .756$ ve $.692 ; \mathrm{p}<.01)$. Faktörlerin kendi aralarında ise, düşük ve orta düzeyde pozitif ve anlamlı bir korelasyonun olduğunu görülmektedir ( $\mathrm{r}=.501$, $.499, .362, .457, .408$ ve $.294 ; \mathrm{p}<.001)$. Şencan (2005) faktör analizi sonucunda iki, üç veya dört faktörlü yapı elde edilmişse ve bu faktörlerin kendi aralarındaki korelâsyon katsayıları yüksekse (.60 ve üstü) boyutların birbirleriyle bağımlı olduğunu ve tek bir yapıyı ölçtüğünü ifade etmektedir. Bu durumdan hareketle ölçekte yer alan faktörlerin kendi aralarındaki (r) değişkeni katsayılarının .60'ın altında olmasından dolayı her faktörün ayrı bir özelliği ölçtügünü ve bu alt faktörlerin ölçeğin geneline hizmet ettiği söylenebilir.

\section{2. Güvenirlik Analizi}

Yapılan güvenilirlik çalışmaları neticesinde, tüm ölçeğin Cronbach Alpha iç tutarlılık katsayısı ve ölçme aracının her alt boyutu için iç tutarlılık katsayıları incelenmiştir. Tablo 4'de görüldüğü üzere "Eyleme Dönük Sorumluluk" alt boyutu için iç tutarlılık katsayısı .88, "Ekolojik Sorumluluk" alt boyutu için iç tutarlılık katsayısı .74, "Özgeci Sorumluluk" alt boyutu için iç tutarlılık katsayısı .77, "Ulusal Sorumluluk" alt boyutu için iç tutarlılık katsayısı .73‘tür. Ölçeğin tümü için elde edilen iç tutarlılık katsayısı ise .89 olarak belirlenmiştir. Elde edilen değerler bu ölçeğin güvenilir bir ölçme aracı olduğunu göstermektedir. Kayış'a (2014) göre cronbach alfa katsayısının .80 ile 1 arasında olması ölçeğin yüksek derecede güvenilir olduğunu göstermektedir. 
Tablo 4. Küresel Sosyal Sorumluluk Ölçeği Güvenirlik Analizi Sonuçları

\begin{tabular}{cc}
\hline Faktörler & Cronbach Alpha $(\alpha)$ değeri \\
\hline Eyleme Dönük Sorumluluk & .88 \\
Ekolojik Sorumluluk & .74 \\
Özgeci Sorumluluk & .77 \\
Ulusal Sorumluluk & .73 \\
Toplam & .89 \\
\hline
\end{tabular}

$\mathrm{Bu}$ çalışmada sosyal bilgiler öğretmen adaylarının küresel sosyal sorumluluk düzeylerini ölçmeye yönelik geliştirilen ölçeğin geçerlik ve güvenirliği hesaplanmıştır. Küresel sosyal sorumluluk ölçeğinin geliştirilmesi amacıyla ilgili literatür taranmış ardından sosyal sorumluluğu küresel boyuta taşıyacak evrensel değerler (eşitlik, sosyal adalet, dünya barışı, çevreyi koruma, açık fikirlilik, uluslararası işbirliği, doğa ile bütünleşmek, tüm insanlar için refah) göz önüne alınarak ölçek maddeleri oluşturulmuştur. Oluşturulan maddelerin kapsam geçerliği, Ölçme Değerlendirme, Türkçe ve Sosyal Bilgiler Öğretimi öğretim üyesi ve elemanlarından oluşan yedi uzman yardımıyla incelenmiştir. Elde edilen 48 maddelik ölçeğin yap1 geçerliği için ise açımlayıcı faktör analizi kullanılmıştır. Çalışmanın yürütüldüğü araştırma grubu ise 327 kişiden oluşan sosyal bilgiler öğretmen adaylarından oluşmaktadır.

Faktör analizinden önce elde edilen verilerin faktör analizine uygunluğunu belirlemek amacryla, Kaiser-Meyer-Olkin (KMO) örneklem uygunluğu testi ve Bartlett Sphericity testi yapılmıştır. Kaiser-Meyer-Olkin örneklem uygunluğu değerinin .86 ve Bartlett Sphericity testinin anlamlılık seviyesinin .000 çıkması ( $\mathrm{p} \leq .05$ için), verilerin faktör analizine uygun olduğunu göstermiştir. Veri seti üzerinden yapılan faktör analizinde faktör özdeğeri 1'den büyük olan faktörler anlamlı olarak belirlenmiş, temel bileşenler analizi öncelikli olmak üzere varimax eksen döndürmesi gerçekleştirilmiştir. Yamaç Eğim Grafiği (Scree Plot) incelenerek ölçeğin 4 faktörlü olması gerektiği sonucuna varılmıştır. Açımlayıcı faktör analizinde maddelerin ölçekte kalıp kalmamasına karar vermede faktör yük değerinin alt sınırı
.45 olarak benimsenmiştir. Ayrıca faktör yüklerinin binişik sayılmaması için aralarındaki farkın en az 0,1 olması önerilmektedir. Ancak gerçekleştirilen analizler sonucu .40 üzerinde fakat $.45^{\prime}$ den düşük değer gösteren 41 . maddenin ölçekte kalmasına karar verilmiştir. Büyüköztürk'e (2011) göre Faktör yük değerlerinin .45 yada daha yüksek olması seçim için iyi bir ölçüt olmakta ancak uygulamada az sayıda madde için bu sınır .30'a kadar indirilebilmektedir. Buna göre faktör yük değerini karşılamayan ve binişik olduğu tespit edilen 18 madde ölçekten çıkarılmıştır. Sosyal bilgiler öğretmen adaylarının küresel sosyal sorumluluklarını ölçmeye yönelik 30 maddelik ölçek oluşturulmuştur. Faktörler barındırdıkları maddelerin içerdiği ifadelere göre isimlendirilmiştir. Bu bağlamda birinci faktör "Eyleme Dönük Sorumluluk" (12 madde), ikinci faktör "Ekolojik Sorumluluk" (5 madde), üçüncü faktör "Özgeci Sorumluluk" (7 madde), dördüncü faktör ise "Ulusal Sorumluluk" (6 madde) olarak isimlendirilmiştir. Açıklanan toplam varyans ise $\% 47,229$ olarak bulunmuştur.

Yapı geçerliliğine ek kanıt olarak ölçeğin boyutları ve genel toplam puanı arasındaki ilişkiler incelenmiş olup Pearson Korelasyon katsayıları hesaplanmıştır. Küresel sosyal sorumluluk ölçeğinden alınan toplam puanlar ile bu ölçeğin alt faktörleri arasındaki korelâsyon katsayısı sonuçları incelendiğinde orta ve yüksek düzeyde pozitif bir ilişki çıkmıştır ( $\mathrm{r}=.858$, $.668, .756$ ve .692; $\mathrm{p}<.01$ ). Faktörlerin kendi aralarında ise, düşük ve orta düzeyde pozitif ve anlamlı bir korelasyonun olduğunu görülmektedir $(r=.501, .499, .362, .457, .408$ ve .294; $\mathrm{p}<.001)$. Bu durumdan hareketle ölçekte yer alan faktörlerin kendi aralarındaki (r) değişkeni 
katsayılarının .60'in altında olmasından dolayı her faktörün ayrı bir özelliği ölçtüğü ve bu alt faktörlerin ölçeğin geneline hizmet ettiği söylenebilir.

Otuz maddelik ölçeğin güvenirliğine ilişkin bulgular için de Cronbach Alfa katsayıları hesaplanmış ve ölçeğin tamamında .89 , ilk alt boyutunda .88 , ikinci alt boyutunda .74 , üçüncü alt boyutunda .77 ve dördüncü alt boyutunda ise .73 bulunmuştur.

Küresel sosyal sorumluluğun ölçülmesine yönelik gerçekleştirilen bu araştırmanın sonucunda 30 maddeli (21'i olumlu, 9'u olumsuz), Cronbach Alfa katsayısı .89 olan ve toplam varyansın \%47,229'unu açıklayan dört boyutlu küresel sosyal sorumluluk ölçeği geliştirilmiş- tir. Nihai ölçekte yer alan 3, 7, 11, 17, 18, 20, 21, 26 ve 27 numaralı maddeler olumsuz, diğer maddeler ise olumlu yargı içermektedir. Eyleme dönük sorumluluk: 1, 19, 16, 30, 5, 6, 14, 28, 9, 10, 24, 12; ekolojik sorumluluk: 25, 7, 15, 2, 17; özgeci sorumluluk: 18, 11, 20, 4, 22, 23, 29; ulusal sorumluluk: $21,26,27,13,3,8$ numaralı maddelerden oluşmaktadır.

$\mathrm{Bu}$ çalışmanın sonuçları, elde edilen ölçeğin geçerli ve güvenilir bir ölçme aracı olarak kullanılabileceğini göstermektedir. Bu ölçeğin, öğretmen adaylarının küresel sosyal sorumluluk düzeyleri konusunda çalışma yapmak isteyen alandaki uzmanlar tarafından kullanılabileceği düşünülmektedir.

\section{Kaynakça}

Berkowitz, L. ve Lutterman, K. G. (1968). The traditional socially responsible personality. The Public Opinion Quarterly, 32 (2), 169-185.

Berman, S. (1990). Educating for social responsibility. Educational Leadership, 48 (3), 75-80.

Bozkurt. S. (2009). Toplumsal sorumluluk ve bilinçlendirme kampanyaları: TEMA vakfı örneği (Yayınlanmamış yüksek lisans tezi). İstanbul Kültür Üniversitesi Sosyal Bilimler Enstitüsü, İstanbul.

Büyüköztürk, Ş. (2007). Sosyal bilimler için veri analizi el kitabı: İstatistik, araştırma deseni, SPSS uygulamaları ve yorum (7. Baskı). Ankara: Pegem Akademi Yayıncılık.

Büyüköztürk, Ş. (2011). Sosyal bilimler için veri analizi el kitabı:İstatistik, araştırma deseni, SPSS uygulamaları ve yorum (14. Bask1). Ankara: Pegem Akademi.

Çelik, A. (2007). İşletmelerin sosyal sorumlulukları. İçinde C. C. Aktan (Ed) Kurumsal sosyal sorumluluk, işletmeler ve sosyal sorumluluk (s. 61-85). İstanbul: İgiad Yayınları.

Çokluk, Ö., Şekercioğlu, G., ve Büyüköztürk, Ş. (2012). Sosyal bilimler için çok değişkenli istatistik SPSS ve lisrel uygulamaları (2. Baskı). Ankara: Pegem Akademi.

Dökmen. Ü. (2000). Yarına kim kalacak? Evrenle uyumlaşma sürecinde varolmak gelişmek uzlaşmak (12. Baskı). İstanbul: Sistem Yayınları.

Duman, A. (2014). Okulların sosyal sorumluluk görevlerini yerine getirebilme yeterliliği. (Yayınlanmamış yüksek lisans tezi) Yeditepe Üniversitesi Sosyal Bilimler Enstitüsü, İstanbul.

Eraslan, L. (2011). Bireysel sosyal sorumluluk ölçeğinin (BSS) geliştirilmesi: Geçerlik ve güvenirlik çalışması. Ĕ̆itim Kültür ve Araştırma Dergisi, 7 (24), 81-91.

Ercan, B. (2009). Ortaöğretim öğretmenlerinin sosyal sorumluluk anlayış ve uygulamaları: Antalya örneği (Yayınlanmamış yüksek lisans tezi). Akdeniz Üniversitesi Sosyal Bilimler Enstitüsü, Antalya.

Eren, S. (2011). İlköğretim velilerinin okul yöneticilerinden sosyal sorumluluk görevlerine ilişkin beklentileri (Bağcılar ilçesi örnĕ̆i). Yayınlanmamış yüksek lisans tezi, Yeditepe Üniversitesi Sosyal Bilimler Enstitüsü, İstanbul. 
Güngör, C. R. (2010). Kurumsal sosyal sorumluluk kampanyalarının işletmeye olan katkıları. Yayınlanmamış yüksek lisans tezi, İstanbul Üniversitesi Sosyal bilimler Enstitüsü, İstanbul.

Hull, D. L. (2002). The social responsibility of Professional societies. Metaphilosophy. 33 (5), 552-565. ISSN: 0026-1068.

İşseveroğlu, G. (2001). İşletmelerde sosyal sorumluluk ve etik. Yönetim ve Ekonomi, 8 (2), 55-67.

Kayış, A. (2014). Güvenilirlik analizi (reliability analysis). Iç̧inde Ş. Kalaycı (Ed.) SPSS uygulamalı çok değişkenli istatistik teknikleri (s. 403-419). Ankara: Asil Yayın Dağıtım.

Nakamura, M. ve Watanabe-Muraoka, A. M. (2006). Global social responsibility: developing a scale for senior high school students in Japan. International Journal for the Advancement of Counselling, 213226.

Öcal, A., Demirkaya, H. ve Altınok, A. (2013). İlköğretim öğrencilerine yönelik sosyal duyarlılık ölçeğinin geliştirilmesi. Pegem Ĕ̆gitim ve Öğretim Dergisi, 3 (1), 67-76.

Önal, Ş. H. (2005). Bir sorumluluk eğitim programının lise dokuzuncu sınıf öğrencilerinin sorumluluk düzeylerine etkisi. Yayınlanmamış yüksek lisans tezi, Uludağ Üniversitesi Sosyal Bilimler Enstitüsü, Bursa.

Özen, Y. (2009). İlköğretim 8. sını öğrencilerinin kişisel ve sosyal sorumluluk yordayıcılarının incelenmesi. Yayınlanmamış doktora tezi, Atatürk Üniversitesi Sosyal Bilimler Enstitüsü, Erzurum.

Öztürk, M. (2003). Fonksiyonları açısından işletme ve yönetim. İstanbul: Papatya Yayıncılık.

Pelit, E., Keleş, Y. ve Çakır, M. (2009). Otel işletmelerinde sosyal sorumluluk uygulamalarının belirlenmesine yönelik bir araştırma. Yönetim ve Ekonomi: Celal Bayar Üniversitesi İktisadi ve İdari Bilimler Fakültesi Dergisi, 16 (2), 19-30.

Richardson, P. (2012). Teaching with a global perspective. Inquiry: The Journal of the Virginia Community Colleges, 17 (1), 43-50.

Schwartz, S. H. (1992). Universals in the content and structure of values: Theoretical advances and empirical tests in 20 countries. Advances in experimental social psychology, 25 (1), 1-65.

Sert, N. Y. (2012). Türkiye'de özel sektörün kurumsal sosyal sorumluk anlayışına ilişkin yarar algısı: Kurumsal sosyal sorumluluk faaliyetlerinin duyurulmasında web sitelerinin kullanılması. AJIT-e: Online Academic Journal of Information Technology, 3 (9), 31-50. ISSN: 1309-1581.

Sezer, T. (2008). Illköğretim 6. sinıf sosyal bilgiler dersinde sorumluluk değgrinin öğretimine ilişkin öğretmen görüşleri. Yayınlanmamış yüksek lisans tezi, Gazi Üniversitesi Eğitim Bilimleri Enstitüsü, Ankara.

Starret, R. H. (1996). Assessment of global social responsibility. Psychological reports, 535-554.

Şencan, H. (2005). Sosyal ve davranışsal ölçümlerde güvenilirlik ve geçerlilik. Ankara: Seçkin Yayıncılık.

Şirin, H. (2005). Öğrencilerin sosyal sorumluluklarının geliştirilmesinde öğretmenlerin rolü. Gazi Ĕ̆itim Fakültesi Dergisi, 301-316.

Tam, T. S. ve Yeung, S. (1999). Altruism, social responsibility, and government support for social welfare. Asia Pacific Journal of Social Work and Development, 79-95.

TDK. ( 2014, 8 Aralık). Güncel Türkçe Sözlük. ttp://www.tdk.gov.tr/index.php?option=com_gts\&arama =gts\&guid=TDK.GTS.5485750e017cd6.12226534 adresinden erişilmiştir.

Torlak, Ö. (2003). Pazarlama ahlakı. (2. Baskı). İstanbul: Beta Yayınları.

Torlak, Ö. (2007). Pazarlama ahlakı : Sosyal sorumluluklar ekseninde pazarlama kararları ve tüketici davranışlarının analizi (4 Baskı). İstanbul: Beta Yayınevi. 
86 | SAÜ Eğitim Bilimleri Enstitüsü

Vural, Z. B. ve Coşkun, G. (2011). Kurumsal sosyal sorumluluk ve etik. Gümüşhane Üniversitesi İletişim Fakültesi Elektronik Dergisi, 1 (1), 61-87. ISSN: 2146-3301.

Wildowicz-Giegiel, A. (2014). The evolution and The New frontiers of social responsibility accounting. Problems Of Management In The 21st Century, 9 (1), 95-102. ISSN:2029-6932.

Yavuzer, H. (1995). Ana-Baba ve Çocuk. İstanbul: Remzi Kitabevi.

Yılmaz, K. (2006). Örgütlerin sosyal sorumlulukları: Kavramsal bir çözümleme. Mehmet Akif Ersoy Üniversitesi Eğitim Fakültesi Dergisi, 65-79. ISSN:1302-8944.

Yılmaz, K. (2011). Egitim fakültelerinin sosyal sorumlulugu ve topluma hizmet uygulamaları dersi: Nitel bir araştırma. Kuramsal Eğitimbilim, 4 (2), 86-108. 


\section{Extended Summary}

The content and structure of education are always changing in accordance with globalization. Therefore, students are facing information about global issues more frequently. So, it is a require to educate 21st century students with the help of teachers who have high awareness and more information about global issues. Teaching paradigm should be renewed in accordance with the changing universal conditions and in order to provide new demands and needs. Teachers who have adopted globalization should equip their students with the necessary abilities, skills and knowledge (Richardson 2012). These knowledge and abilities acquire deeper meanings and evolve into a great power in the hands of people who has reached to the responsibility to use them for the benefit of society and mankind. Especially acting with the help of responsibility which is felt for the sake of society and is based on voluntariness will enhance prosperity of society, the quality and standard of life and will enable desired society structure and will contribute to the world formation. So the aim of this study; is to develop a scale which will evaluate global social responsibilities of teacher candidates who will educate future generations which will lay the foundations of societies.

In this study, validity and reliability of the scale, which has been developed to evaluate social responsibility levels of social studies prospective teachers, have been calculated. First, related books and articles are studied in order to develop the social responsibility scale and then the scale items are created according to universal values (equality, social justice, world peace, environmental control, openmindedness, international cooperation, integrating with nature, prosperity for all people). Content validity of the items created have been examined with the help of seven Turkish and Social Studies academic members and experts. Exploratory factor analysis has been used for the scale which has 48 items. Also, the research staff of this study includes 327 social studies prospective teachers. Kaiser-MeyerOlkin measure of sampling adequacy (KMO) and Bartlett Sphericity test have been carried out in order to indicate whether data are appropriate or not for factor analysis. Kaiser-Meyer-Olkin measure of sampling adequacy result is .86 and Bartlett Sphericity test result is .000 so (for $p \leq .05$ ) it is appropriate for factor analysis.

During factor analysis according to data set factors which have a latent value bigger than 1 are specified as significant; principal components analysis being in the first place varimax rotation has been applied. It is concluded that the scale should have 4 factors by examining the Slope Chart (Scree Plot). Deciding whether the items should remain within the scale or eliminate during factor analysis, lower factor loading value limit is accepted as .45. Also, it is suggested that the variation between factor loads must be at least 0,1 so that they aren't regarded as comorbid. However, it is decided that item 41 must remain within the scale which has a value bigger than .40 but smaller than .45 according to results of analysis carried out. Büyüköztürk (2011) has suggested that factor loading values .45 or higher are appropriate for selection but while applying for a small number of items the limit can be 30 . So 18 items which do not have required factor loading values and are not comorbid have been eliminated. A scale of 30 items has been created in order to evaluate global social responsibilities of teacher candidates. Factors are named according to the terms items have. So, the first factor is named as "Action Oriented Responsibility" (12 items), second factor as "Ecological Responsibility" (5 items), third factor as "Altruist Responsibility" (7 items) and the fourth factor as "National Responsibility" (6 items). Total variance is \%47,229.

As support evidence fort he construct validity the relations between extent of scale and general total points have been examined and Pearson's Correlation coefficients have been calculated. When total points of global social responsibility scale and correlation coefficients results between sub-factors of this scale are examined, medium and high positive relations have been indicated $(\mathrm{r}=.858, .668, .756$ and .692 ; $\mathrm{p}<.01$ ). Also, low and medium positive and meaningful correlation have been detected between factors 
$(\mathrm{r}=.501, .499, .362, .457, .408$ and $.294 ; \mathrm{p}<.001)$. So, in these circumstances because the the factors in the scale have .60 of (r) variable coefficient between themselves, it can be said that each factor evaluates a different feature and these sub-factors serve the scale as a whole.

Cronbach Alpha coefficients are calculated for the findings related to the reliability of scale and it is .89 for the whole scale, .88 for the first sub-dimension, .74 for the second sub-dimension, .77 for the third sub-dimension, .73 for the fourth sub-dimension. In this research, which has aimed to evaluate global social responsibility, a scale of global social responsibility, which has four-dimensional form, 30 items (21 of which are positive and 9 of which are negative), .89 of Cronbach Alpha coefficient and \%47,229 of total variance has been developed. $3,7,11,17,18,20,21,26$ and 27 items in the scale are negative and the other items are positive. Action oriented responsibility items are 1, 19, 16, 30, 5, 6, 14, 28, 9, 10, 24, 12; ecological responsibility items are 25, 7, 15, 2, 17; altruist responsibility items are 18, 11, 20, 4, 22, 23, 29; national responsibility items are $21,26,27,13,3,8$. The scale which has been created with the help of this study can be used as a valid and reliable assessment and evaluation instrument. It is suggested that this scale can be used by the experts who want to make research about global social responsibilities of teacher candidates. 
EK-1:

\begin{tabular}{|c|c|c|c|c|c|c|}
\hline \multicolumn{7}{|c|}{ Küresel Sosyal Sorumluluk Ölçeği } \\
\hline 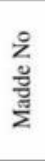 & Maddeler & 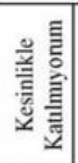 & 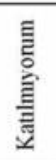 & 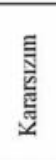 & $\begin{array}{l}\text { 蒠 } \\
\text { 兽 } \\
\text { 兽 }\end{array}$ & 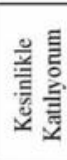 \\
\hline & & 1 & 2 & 3 & 4 & 5 \\
\hline 1 & Küresel sosyal sonumluluk projelerinin olușturulmasında aktif rol oynanm. & & & & & \\
\hline 2 & Çevrenin korunması adına yapabileceğim faydalı bir şeyler olduğunu düşünürüm. & & & & & \\
\hline 3 & Bireyler sadece kendi ülkelerini geliștirmek için çalışmalıdır. & & & & & \\
\hline 4 & Diğer insanların refahım önemserim. & & & & & \\
\hline 5 & Uluslararası sivil toplum kuruluşlannın kampanyalanna destek veririm. & & & & & \\
\hline 6 & Tanıdıklarımı yardım derneklerinin etkinliklerine katılmalan konusunda teşvik ederim. & & & & & \\
\hline 7 & Dünyada çevre kirliliğinin artması beni rahatsız etmez. & & & & & \\
\hline 8 & Komşu ülkelerde var olan problemlerin çözümünde ülkemiz elinden geleni yapmalıdır. & & & & & \\
\hline 9 & $\begin{array}{l}\text { Küresel çevre sorunlarına karș̣ toplumun duyarlığının arınıması çabalarına katkıda } \\
\text { bulunurum. }\end{array}$ & & & & & \\
\hline 10 & Dünyada doğal afetlerden zarar görmüş bölgeler için maddi bağışta bulunurum. & & & & & \\
\hline 11 & Bir bireyin diğer insanlar hakkında endişelenmesine gerek yoktur. & & & & & \\
\hline 12 & $\begin{array}{l}\text { Dünyada medikal ürün bulma sıkıntııı yaşayan insanlara destek olmak amacıyla bağıșta } \\
\text { bulunurum. }\end{array}$ & & & & & \\
\hline 13 & Göçmenlerin (Suriyeli vb.) sorunlarına çŏzüm bulmak için devlet daha fazla çabalamalıdır. & & & & & \\
\hline 14 & $\begin{array}{l}\text { Uluslararası kuruluşlann çevre sorunlannı çözmeye yönelik faaliyetlerini imkânlarım } \\
\text { ölçüsünde desteklerim. }\end{array}$ & & & & & \\
\hline 15 & Insanların üzerinde yaşadığı çevreyi koruması gerektiği anlayışıyla hareket ederim. & & & & & \\
\hline 16 & Tanıdıklarımı uluslararası gönüllü çalışmalara katılmalan konusunda teşvik ederim. & & & & & \\
\hline 17 & Nesli tükenen bitki ve hayvan türlerinin korunması için yapabileceğim bir şey yoktur. & & & & & \\
\hline 18 & Diğer ülkelerdeki insanların sonunlann önemsemem. & & & & & \\
\hline 19 & $\begin{array}{l}\text { Toplumun küresel sosyal sorunlara (dil, ırkçııık vb.) yönelik duyarlığının artırılması } \\
\text { çalışmalannda aktif rol alırm. }\end{array}$ & & & & & \\
\hline 20 & Diğer ülkelerde hak ve özgürlüklerin kısttlanması benim için önemli değildir. & & & & & \\
\hline 21 & Ödediğim vergilerin sadece kendi ülkem / vatandaşlanm için harcanmasıı isterim. & & & & & \\
\hline 22 & Dünyadaki tüm bireyler benim için değerlidir. & & & & & \\
\hline 23 & Az gelişmiş ülkelerdeki yoksul insanlar için yardımda bulunmaya istekliyim. & & & & & \\
\hline 24 & Uluslararası yardım çalışmalarına, yardım amaçı satılan ürùnleri alarak destek olurum. & & & & & \\
\hline 25 & Gazete, şişe, teneke ve benzeri materyallerin geri dönüşümü zorunlu olmalıdır. & & & & & \\
\hline 26 & Başka ülkelere yardım etmek yerine kendi ülkemizdeki sorunları çözmek için uğraşmalıyız. & & & & & \\
\hline 27 & $\begin{array}{l}\text { Türkiye'de yoksul insanlarla ilgili pek çok sorun mevcut olduğundan diğer ülkelerin } \\
\text { sorunlanna para harcamamalıyz. }\end{array}$ & & & & & \\
\hline 28 & $\begin{array}{l}\text { Dünyada gıda sıkıntısı yaşayan ülkeler için yapılan sosyal sorumluluk projelerine destek } \\
\text { veririm. }\end{array}$ & & & & & \\
\hline 29 & Diğer insanlann haklannı gözetirim. & & & & & \\
\hline 30 & Çevre kirliliği ile mūcadele eden kuruluşlarnn çalıșmalarına katılınm. & & & & & \\
\hline
\end{tabular}

